\title{
ARBUSCULAR MYCORRHIZAL FUNGI ENHANCE GROWTH, PHYSIOLOGICAL PARAMETERS AND YIELD OF SALT STRESSED PHASEOLUS MUNGO (L.) HEPPER
}

\author{
NAVNITA SHARMA, ASHOK AGGARWAL*, and KULDEEP YADAV
}

Department of Botany, Kurukshetra University, Kurukshetra, Haryana, India, 136119

* Corresponding author: aggarwal_vibha@rediffmail.com

\section{ABSTRACT}

A pot experiment was conducted in a greenhouse to investigate the effect of two dominant indigenous arbuscular mycorrhizal fungi, viz. Funneliformis mosseae (F) and Acaulospora laevis (A), on the growth of Phaseolus mungo subjected to salinity levels of 4, 8 and $12 \mathrm{dS} \mathrm{m}^{-1}$. Mycorrhizal fungi alone and in combination improved the growth of the plants at all the salinity levels over that of the untreated control plants. However, a combination of $F$. mosseae and A. laevis resulted in maximum root and shoot length, biomass, photosynthetic pigments, protein content, mycorrhization, nodulation, phosphatase activity, phosphorus uptake and yield at the $8 \mathrm{dS}^{-1}$ salinity level. Peroxidase activity and electrolyte leakage were minimum at the $8 \mathrm{dS} \mathrm{m}^{-1}$ salinity level due to improved water absorption as a result of the highest mycorrhization occurring at this level of salinity. Nitrogen and potassium uptake decreased with increase in salinity and highest uptake of these nutrient elements was recorded in the treatment with both mycorrhizal fungi at a salinity level of $4 \mathrm{dS} \mathrm{m}^{-1}$. The results of the present experiment indicate $P$. mungo inoculated with F. mosseae and A. laevis can be successfully cultivated of at salinity level of $8 \mathrm{dS} \mathrm{m} \mathrm{m}^{-1}$. Saline soils with an electrical conductivity of nearly $12 \mathrm{dS} \mathrm{m}^{-1}$ were not suitable for growing this legume.

Keywords: mycorrhizal fungi, Phaseolus mungo, salinity stress, nutrient uptake, peroxidase

\section{Introduction}

The ability of soil to provide necessary nutrients for plants determines its sustainable productivity. The scarcity of micronutrients is one of the factors limiting the stability, productivity and sustainability of soil (Bell and Dell 2008). Soil salinization is a major and increasing problem in different parts of world, especially in dry and semi-arid areas. Nearly $7 \%$ of the land surface in the world is occupied by salt affected soils (Sheng et al. 2011). The most common reasons for increasing land salinization include; excessive use of chemical fertilizers, inadequate drainage as well as irregular irrigation particularly in protected cultivation. Increased concentration of salts in soil disrupts its basic structure causing a reduction in soil porosity and consequently decreased aeration and water conductance (Cucci et al. 2015). In saline soils, plants suffer from different physiological disorders, which affect their overall growth and productivity due to increased osmotic pressure and the harmful effects of $\mathrm{Na}^{+}$and $\mathrm{Cl}^{-}$ions. Increased accumulation of $\mathrm{Na}^{+}$as well as $\mathrm{Cl}^{-}$ions in saline soils causes nutrient imbalance as excess of $\mathrm{Na}^{+}$restrains uptake of $\mathrm{K}^{+}$while excess of $\mathrm{Cl}^{-}$ions slows down $\mathrm{NO}_{3}^{-}$ uptake (Turkmen et al. 2005). Salinity stress in plants is associated with increased production of reactive oxygen species, which causes oxidative damage resulting in the oxidation of lipids, proteins and chlorophyll causing membrane leakage as well as damage to nucleic acids. In response to this plants have complex antioxidant system including enzymes like catalase (CAT), superoxide dismutase (SOD) and peroxidase (POX) and some non-enzymatic molecules like glycine, proline, betaine, sorbitol and mannitol to protect them from oxidative damage due to salinity stress (Parvaiz and Satyawati 2008).
To cope up with the increasing problem of soil salinity, development of inbred crop plants that are tolerant of salinity stress and other physiochemical methods have been tried but have failed because of physiological or genetical trait complexity (Flowers and Flowers 2005; Munns 2005). The use of plant growth promoting microorganisms as a useful and practical way to ameliorate salinity stress has received much attention in recent years. Among the plant growth promoting microorganisms, the role of arbuscular mycorrhizal fungi in improving soil structure and alleviating salinity stress is well established (Ahanger et al. 2014). Mycorrhizal associations are widely recorded in saline soils and are able to utilize water and mineral salts more efficiently than roots of plants. These symbiotic fungi act as bio-alleviators of salinity stress by improving nutrient uptake, chlorophyll content, antioxidant enzyme activity, membrane stability, vegetative growth and phosphatase activity thus reducing the damage to plants caused by salinity stress (Sheng et al. 2011; Beltrano et al. 2013). Since legumes establish a tripartite association with rhizobacteria and AMF, it is recommended that legumes are inoculated with these microbes, which may assist phosphorus and nitrogen uptake resulting in improvement of growth and productivity under salinity stress.

Among the different food legumes, Phaseolus mungo (L.) Hepper pulses are highly nutritious containing $60 \%$ carbohydrate, $24 \%$ protein and $1.3 \%$ fat, plus minerals like calcium, phosphorus, potassium and vitamins like A, B and C (Sarwar et al. 2004). It is one of the most highly prized pulses in India. This country is the largest producer of $P$. mungo in the world. The hazardous effect of salt in the soil on the productivity of legumes is the major problem confronted by the farmers throughout 
the world. Thus the ability of AMF to ameliorate salinity stress and improve the tolerance of $P$. mungo of salt could have important practical applications. The present experiment aimed to investigate the growth response of $P$. mungo grown at different levels of salinity and the role of AMF in improving growth and yield when grown in saline soils.

\section{Materials and Methods}

\section{Growth Conditions}

A pot experiment was conducted in a glass house at the Botany Department, Kurukshetra University, Kurukshetra, Haryana, India. The temperature was maintained at $\left(30 \pm 5{ }^{\circ} \mathrm{C}\right)$ and the relative humidity at $60-70 \%$. Apart from sunlight, light was also provided for 16 hours each day by cool white fluorescent lamps. Soil used in this experiment consisted of $64.2 \%$ sand, $21.81 \%$ silt and $3.90 \%$ clay.

\section{Mass Multiplication of Bioinoculants}

In this experiment, two arbuscular mycorrhizal species viz. Funneliformis mosseae and Acaulospora laevis were used. They were isolated from the rhizosphere of P. mungo grown in the botanical garden of Kurukshetra University, Kurukshetra. After preparation of a starter inoculum using the Funnel Technique of Menge and Timmer (1982), these species were propagated using maize growing in standard pot culture as a host. Mass multiplication of Trichoderma viride was done using a modified wheat bran-saw dust medium (Mukhopadhyay et al. 1986) and the Rhizobium sp. (Bradyrhizobium japonicum) culture (procured from Department of Microbiology, CCS Haryana Agricultural University, India) was multiplied using a nutrient broth medium. Seeds of Phaseolus mungo were procured from CCS Haryana Agricultural University, Hisar, Haryana, India. The seeds were surface sterilized with $0.5 \%(\mathrm{v} / \mathrm{v})$ sodium hypochlorite for 10 minutes and then washed with sterilized distilled water. Before seeds were sown in pots, $10 \mathrm{ml}$ of a liquid suspension of Bradyrhizobium sp. was applied to each pot. Ten days after emergence the number of plants was reduced to 5 per pot.

\section{Experimental Setup}

The experiment was laid out in a randomized block design, with five replicates of each treatment. Soil from the experimental site was collected and mixed with sand in a ratio of 3:1 (soil : sand). This mixture was then sieved through $2-\mathrm{mm}$ sieve and autoclaved at $121{ }^{\circ} \mathrm{C}$ for two hours for two consecutive days to render it free of naturally occurring microbes, including mycorrhizal fungi. After sterlization, the soil was then tested for the presence of microbes and it was found to be completely free of microbes. This was done to avoid the effect of other microbes on the growth response of $L$. culinaris under salinity stress. The Earthenware pots $(24.5 \times 25 \mathrm{~cm})$ were selected and filled with $2.5 \mathrm{~kg}$ soil. Initially, the pots were saturated with three different levels of saline solution, i.e. 4, 8, and $12 \mathrm{dS} \mathrm{m}^{-1}$ (sodium chloride, calcium chloride and sodium sulphate in the ratio 7:2:1 w/v) as per Richards (1954). Then, pieces of maize root with $85 \%$ colonization by AM were chopped up and along with soil containing AM spores (620-650 per $100 \mathrm{~g}$ inoculum) were used as the AM inoculum. To each pot $10 \%(\mathrm{w} / \mathrm{w})$, i.e. $200 \mathrm{~g} / \mathrm{pot}$ inoculum of AM fungi alone and in combination was added to the soil before sowing the seeds. Pots were watered regularly with saline solution to maintain the required salinity level and were fertilized with a nutrient solution after 15 days (Weaver and Fredrick 1982), which contained half the recommended level of phosphorus and no nitrogen. For each level of salinity there were 4 treatments as outlined below:

1. Uninoculated (without AM inoculum but with Bradyrhizobium sp.)

2. Funneliformismosseae (F) with Bradyrhizobium sp.

3. Acaulospora laevis (A) with Bradyrhizobium sp.

4. F + A with Bradyrhizobium sp.

\section{Plant Harvest and Analysis}

After 120 days, plants were harvested by uprooting them and then various morphological and physiological parameters were measured. Plant height and root length were measured. For determining fresh and dry weight, roots and shoots were weighed after uprooting and then oven dried at $70{ }^{\circ} \mathrm{C}$ until a constant dry weight was obtained. Chlorophyll content was determined by using the method of Arnon (1949). Root and shoot phosphorus content was estimated using the "Vanado-molybdo-phosphoric yellow colour method' (Jackson 1973) and nitrogen $(\mathrm{N})$ content was determined using the Kjeldahl method (Kelplus nitrogen estimation system, supra-LX, Pelican Equipments, Chennai, India). Potassium content was analyzed using inductively coupled plasma analyzer-mass spectrometry (ICP-MS). Phosphatase activity was estimated using p-nitrophenyl phosphate (PNPP) as a substrate, which is hydrolyzed by the enzyme to p-nitrophenol (Tabatabi and Bremner 1969). Total protein was estimated using Bradford's (1976) method. Peroxidase activity was determined using Maehly's method (1954). Leaf area was measured using a leaf area meter (Systronics 21, Ahmedabad, India). Nodulation and yield in terms of number and weight of pods ( $\mathrm{g}$ ) per pot was recorded after 120 days.

\section{Identification and Quantification of the Number and Colonization by AM Spores}

Identification of AM spores ( $F$. mosseae and A. laevis) was done using the identification manuals of Walker (1983); Scheneck and Perez (1990); Morton and Benny (1990) and Mukerji (1996). Quantification of AM spores was done using the Adholeya and Gaur 'Grid Line Intersect Method' (1994). 'Rapid Clearing and Staining' technique of Phillips and Hayman (1970) was used to estimate mycorrhizal colonization of roots. The latter was 
calculated using the formula: (Number of root segments colonized / number of root segments studied) $\times 100$.

\section{Electrolyte Leakage}

To determine electrolyte leakage, fresh leaf samples (200 mg) were cut into small discs (i.e. $5 \mathrm{~mm}$ in diameter) and placed in test tubes containing $10 \mathrm{ml}$ of distilled and deionized water. The tubes sealed with cotton plugs were placed in a water bath at a constant temperature of $32 \pm 8{ }^{\circ} \mathrm{C}$. After $2 \mathrm{~h}$ the initial electrical conductivity of the medium (EC1) was measured using an electrical conductivity meter. Afterwards the samples were autoclaved at $121 \pm 8^{\circ} \mathrm{C}$ for 20 minutes to kill the tissues and release all electrolytes. The samples were then cooled to $25 \pm 8^{\circ} \mathrm{C}$ and final electrical conductivity (EC2) was measured. The electrolyte leakage (EL) was calculated using the formula of Dionisio-Sese and Tobita:

$$
\mathrm{EL}=\mathrm{EC} 1 / \mathrm{EC} 2 \times 100
$$

\section{Statistical Analysis}

Data were subjected to an analysis of variance and means separated using the least significant difference test in the Statistical Package for Social Sciences (ver.11.5, Chicago, IL, USA).

\section{Results}

\section{Growth}

\section{Plant Height and Shoot Biomass}

In the present investigation, mycorrhizal plants were taller than non-mycorrhizal control plants (Table 1).
Maximum height was recorded for the plants treated with the dual combination of $\mathrm{F}+\mathrm{A}$ and growing in soil with a $8 \mathrm{dS} \mathrm{m}^{-1}$ (medium) salinity level followed by the same treatment but with plants growing in soil with a $4 \mathrm{dS} \mathrm{m}^{-1}$ (low) salinity level. In this experiment, untreated control plants subjected to a $12 \mathrm{dS} \mathrm{m}^{-1}$ salinity level were the smallest. This was reflected in the fresh and dry weights of the shoots. Highest shoot weight was recorded for $\mathrm{F}+\mathrm{A}$ plants grown in soil with a medium salinity level $\left(8 \mathrm{dS} \mathrm{m}^{-1}\right)$ followed by the same treatment at the low salinity level $\left(4 \mathrm{dS} \mathrm{m}^{-1}\right)$. The shoot fresh weight of the control plants was the same when grown in soil with both a $12 \mathrm{dS} \mathrm{m}^{-1}$ and $4 \mathrm{dS} \mathrm{m}^{-1}$ salinity level. Inoculation of plants with F. mosseae proved to be more beneficial for increasing shoot fresh weight at a high salinity $\left(12 \mathrm{dS} \mathrm{m}^{-1}\right)$ than a low salinity level $\left(4 \mathrm{dS} \mathrm{m}^{-1}\right)$. In the un-inoculated plants, dry shoot weight decreased with increase in salinity while among the treated plants, inoculation with $\mathrm{F}+\mathrm{A}$ at a medium salinity level $\left(8 \mathrm{dS} \mathrm{m}^{-1}\right)$ gave the best results, as shown in Table 1 .

\section{Root length and root biomass}

Root length and fresh and dry weights were highest for plants subjected to a medium salinity level $\left(8 \mathrm{dS} \mathrm{m}^{-1}\right)$ followed by those subjected to a low salinity level $\left(4 \mathrm{dS} \mathrm{m}^{-1}\right)$ and treatment $\mathrm{F}+\mathrm{A}$ was the best of all the treatments (Table 1).

\section{Leaf Area}

Maximum leaf area was recorded for plants grown at the highest salinity level $\left(12 \mathrm{dS} \mathrm{m}^{-1}\right)$ followed by those grown at the lowest salinity level $\left(4 \mathrm{dS} \mathrm{m}^{-1}\right)$ when they

Table 1 Effect of AM fungi on the growth of Phaseolus mungo grown under different levels of salinity stress.

\begin{tabular}{|c|c|c|c|c|c|c|c|}
\hline \multirow{2}{*}{$\begin{array}{l}\text { Salinity } \\
\text { level }\end{array}$} & \multirow{2}{*}{$\begin{array}{l}\text { Parameters } \rightarrow \\
\text { Treatments } \downarrow\end{array}$} & \multirow{2}{*}{$\begin{array}{l}\text { Plant Height } \\
\text { (cm) }\end{array}$} & \multicolumn{2}{|c|}{ Shoot weight (g) } & \multirow{2}{*}{$\begin{array}{l}\text { Root Length } \\
(\mathrm{cm})\end{array}$} & \multicolumn{2}{|c|}{ Root weight (g) } \\
\hline & & & Fresh & Dry & & Fresh & Dry \\
\hline & $\mathrm{C}$ & $31.58 \pm 2.140^{f}$ & $0.69 \pm 0.019 \mathrm{gh}$ & $0.29 \pm 0.006^{\mathrm{h}}$ & $04.74 \pm 0.350 \mathrm{~g}$ & $0.35 \pm 0.121^{\mathrm{ef}}$ & $0.15 \pm 0.044^{f}$ \\
\hline \multirow[t]{4}{*}{$4 \mathrm{dS} \mathrm{m}^{-1}$} & $\mathrm{~F}$ & $59.46 \pm 1.611^{d}$ & $6.37 \pm 0.304^{d}$ & $2.12 \pm 0.246^{d}$ & $12.76 \pm 0.371^{d}$ & $0.69 \pm 0.114^{c d}$ & $0.42 \pm 0.277 b^{c d}$ \\
\hline & $A$ & $38.44 \pm 1.849^{e f}$ & $3.70 \pm 0.248^{e f}$ & $1.23 \pm 0.027^{\mathrm{ef}}$ & $10.02 \pm 0.370^{f}$ & $0.55 \pm 0.090^{\mathrm{de}}$ & $0.33 \pm 0.167 \mathrm{cde}$ \\
\hline & $F+A$ & $78.10 \pm 1.063^{b}$ & $8.45 \pm 0.043^{b}$ & $2.90 \pm 0.027^{c}$ & $15.62 \pm 0.238^{b}$ & $0.82 \pm 0.159^{b c}$ & $0.45 \pm 0.085^{b c}$ \\
\hline & $\mathrm{C}$ & $33.38 \pm 1.583^{f}$ & $0.84 \pm 0.002 \mathrm{~g}$ & $0.11 \pm 0.003^{i}$ & $05.28 \pm 0.334 \mathrm{~g}$ & $0.59 \pm 0.231^{d}$ & $0.18 \pm 0.356^{\mathrm{ef}}$ \\
\hline \multirow[t]{4}{*}{$8 \mathrm{dS} \mathrm{m}^{-1}$} & $\mathrm{~F}$ & $69.38 \pm 1.344^{c}$ & $7.92 \pm 0.311^{c}$ & $3.42 \pm 0.340^{\mathrm{b}}$ & $14.16 \pm 0.304^{c}$ & $0.97 \pm 0.246^{a b}$ & $0.55 \pm 0.211^{b f}$ \\
\hline & A & $37.70 \pm 0.113^{e f}$ & $4.43 \pm 0.266^{e}$ & $1.41 \pm 0.024^{\mathrm{e}}$ & $11.24 \pm 0.288^{\mathrm{e}}$ & $0.73 \pm 0.090^{c d}$ & $0.33 \pm 0.137^{\text {cde }}$ \\
\hline & $F+A$ & $86.40 \pm 1.414^{a}$ & $9.40 \pm 0.218^{a}$ & $4.14 \pm 0.030^{a}$ & $16.34 \pm 0.397^{a}$ & $1.07 \pm 0.105^{a}$ & $0.85 \pm 0.071^{a}$ \\
\hline & C & $28.00 \pm 1.046^{g}$ & $0.69 \pm 0.002^{g h}$ & $0.06 \pm 0.003^{i}$ & $03.96 \pm 0.336^{h}$ & $0.18 \pm 0.005^{f}$ & $0.10 \pm 0.036^{f}$ \\
\hline \multirow[t]{5}{*}{$12 \mathrm{dS} \mathrm{m}^{-1}$} & $\mathrm{~F}$ & $29.68 \pm 1.948^{f g}$ & $4.28 \pm 0.173^{e}$ & $1.16 \pm 0.023^{e f}$ & $11.68 \pm 0.238^{e}$ & $0.56 \pm 0.245^{\mathrm{de}}$ & $0.15 \pm 0.066^{f}$ \\
\hline & $A$ & $37.86 \pm 1.292^{\mathrm{ef}}$ & $2.16 \pm 0.028^{f}$ & $0.92 \pm 0.0039$ & $09.30 \pm 0.412^{f}$ & $0.33 \pm 0.156^{f}$ & $0.12 \pm 0.044^{f}$ \\
\hline & $F+A$ & $40.04 \pm 1.275^{e}$ & $7.62 \pm 0.023^{c}$ & $1.58 \pm 0.040^{e}$ & $13.88 \pm 0.303^{c}$ & $0.64 \pm 0.109^{c d}$ & $0.27 \pm 0.049$ def \\
\hline & L.S.D $(P \leq 0.05)$ & 906.3620 & 163.5300 & 488.9330 & 803.3010 & 13.9140 & 14.4890 \\
\hline & ANOVA $_{(11,24)}$ & 1.9185 & 0.2239 & 0.1697 & 0.4238 & 0.1984 & 0.1631 \\
\hline \multirow[t]{3}{*}{ F values } & Salinity (S) & 1271.0250 & 649.4820 & 507.2890 & 189.3410 & 35.8350 & 30.9380 \\
\hline & Treatments ( $\mathrm{T}$ ) & 1799.3160 & 5.3780 & 1233.8870 & 2809.0000 & 26.8620 & 23.6350 \\
\hline & $\mathrm{S} \times \mathrm{T}$ & 341.9970 & 91.9030 & 110.3380 & 5.1210 & 0.1330 & 4.4330 \\
\hline
\end{tabular}

Legend:F†: Funneliformis mosseae, A: Acaulospora laevis, $\neq$ : each value is the mean of five replicates, \pm : standard deviation, AM: Arbuscular mycorrhizae, values in columns followed by the same letter are not significantly different, $\mathrm{P} \leq 0.05$, least significant difference test. 
were treated with $\mathrm{F}+\mathrm{A}$ (Table 5). Among the single inoculation treatments and control, the maximum leaf areas were recorded for plants grown in soil with a medium

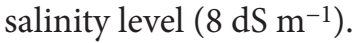

\section{Chlorophyll Content}

Content of photosynthetic pigments recorded in AM treated plants grown in soils with different levels of salinity were higher than in un-inoculated control plants (Table 2). However, the highest total chlorophyll content was recorded for plants treated with a combination of F. mosseae and A. laevis followed by a single inoculation with $F$. mosseae and grown in soil with a salinity level of $8 \mathrm{dS} \mathrm{m} \mathrm{m}^{-1}$. Further increase in salinity to $12 \mathrm{dS} \mathrm{m}^{-1}$ resulted in a decrease in chlorophyll content. Lowest concentration of photosynthetic pigments was recorded in untreated plants grown in soils with a $12 \mathrm{dS} \mathrm{m}^{-1}$ salinity level.

\section{Protein Content}

Regardless of mycorrhizal treatments, a salinity level of $8 \mathrm{dS} \mathrm{m}^{-1}$ resulted in remarkable increase in leaf protein content (Table 2). Further, increase in salinity to $12 \mathrm{dS} \mathrm{m}^{-1}$ had an adverse effect on leaf protein content. The protein content increased with increase in soil salinity up to $8 \mathrm{dS} \mathrm{m} \mathrm{m}^{-1}$. Although, further increase in soil salinity resulted in a decrease in the content of protein in leaves; inoculation with F. mosseae and A. laevis increased protein content to the maximum level, followed by treat- ment with $A$. laevis alone, indicating its stimulatory effect on protein synthesis at all the levels of salinity used.

\section{Mycorrhization}

As evident from Table 2, the plants subjected to a medium salinity level $\left(8 \mathrm{dS} \mathrm{m}^{-1}\right)$ had a greater number of AM spores and \% root colonization as compared to higher and lower salinity levels. Beyond the medium salinity level, i.e. at (12 $\left.\mathrm{dS} \mathrm{m}^{-1}\right)$, there was a negative correlation between salinity and mycorrhization. Maximum mycorrhization was recorded in the combined treatment $\mathrm{F}+\mathrm{A}$ of plants grown in soil with a salinity level of $8 \mathrm{dS} \mathrm{m} \mathrm{m}^{-1}$ followed by that recorded for plants treated only with $F$. mosseae, which indicates that F. mosseae is more tolerant of salinity than A. laevis.

\section{Nodulation}

In un-inoculated control plants, nodulation decreased with increase in salinity level but in plants treated with AM fungi, nodulation increased up to maximum level at a salinity level of $8 \mathrm{dS} \mathrm{m} \mathrm{m}^{-1}$ and was much lower at a salinity of $12 \mathrm{dS} \mathrm{m}^{-1}$ (Table 5).

\section{Peroxidase Activity}

Data presented in Table 3 reveals that peroxidase activity at a salinity level of $8 \mathrm{dS} \mathrm{m} \mathrm{m}^{-1}$ was less than at a salinity level of $4 \mathrm{dS} \mathrm{m}^{-1}$ due to more mycorrhization at a medium salinity level, which improved the water status of plants, which resulted in less osmotic stress. At salinity

Table 2 Effect of AM fungi on some physiological parameters and mycorrhization of Phaseolus mungo grown under different levels of salinity stress.

\begin{tabular}{|c|c|c|c|c|c|c|c|}
\hline \multirow{2}{*}{$\begin{array}{l}\text { Salinity } \\
\text { level }\end{array}$} & \multirow{2}{*}{$\begin{array}{l}\text { Parameters } \rightarrow \\
\text { Treatments } \downarrow\end{array}$} & \multicolumn{3}{|c|}{ Chlorophyll content (mg/g FW) } & \multirow{2}{*}{$\begin{array}{l}\text { Protein content } \\
\quad(\mathrm{mg} / \mathrm{g} \mathrm{FW})\end{array}$} & \multirow{2}{*}{$\begin{array}{c}\text { AM spore } \\
\text { number / } 10 \mathrm{~g} \\
\text { of soil }\end{array}$} & \multirow{2}{*}{$\begin{array}{l}\text { AM Root colo- } \\
\text { nization (\%) }\end{array}$} \\
\hline & & Chl a & Chl b & Total Chl & & & \\
\hline & $\mathrm{C}$ & $0.714 \pm 0.004^{k}$ & $0.358 \pm 0.019^{j}$ & $1.0718 \pm 0.012^{k}$ & $0.191 \pm 0.003^{k}$ & $06.2 \pm 2.86^{9}$ & $1.98 \pm 2.81^{i}$ \\
\hline \multirow[t]{4}{*}{$4 \mathrm{dS} \mathrm{m}^{-1}$} & $\mathrm{~F}$ & $1.067 \pm 0.004^{d}$ & $0.910 \pm 0.006^{d}$ & $1.978 \pm 0.014^{d}$ & $0.302 \pm 0.002^{g}$ & $63.8 \pm 3.56^{c}$ & $34.4 \pm 4.72^{\mathrm{e}}$ \\
\hline & A & $0.934 \pm 0.003^{g}$ & $0.681 \pm 0.010^{g}$ & $1.616 \pm 0.014^{h}$ & $0.466 \pm 0.002^{d}$ & $51.2 \pm 3.70^{e}$ & $29.9 \pm 3.49^{f}$ \\
\hline & $F+A$ & $1.264 \pm 0.056^{c}$ & $1.040 \pm 0.005^{c}$ & $2.304 \pm 0.011^{c}$ & $0.581 \pm 0.004^{b}$ & $72.6 \pm 4.03^{c}$ & $53.2 \pm 2.86^{b}$ \\
\hline & $\mathrm{C}$ & $0.827 \pm 0.005^{i}$ & $0.411 \pm 0.007^{h}$ & $1.239 \pm 0.023^{i}$ & $0.206 \pm 0.003^{j}$ & $14.8 \pm 3.83^{f}$ & $03.0 \pm 2.23^{i}$ \\
\hline \multirow[t]{4}{*}{$8 \mathrm{dS} \mathrm{m}^{-1}$} & $\mathrm{~F}$ & $1.627 \pm 0.007^{b}$ & $1.317 \pm 0.006^{b}$ & $2.944 \pm 0.010^{b}$ & $0.329 \pm 0.002^{f}$ & $77.6 \pm 3.64^{a}$ & $48.6 \pm 3.49^{c}$ \\
\hline & A & $0.983 \pm 0.006^{e}$ & $0.921 \pm 0.008^{d}$ & $1.905 \pm 0.013^{e}$ & $0.574 \pm 0.002^{c}$ & $65.0 \pm 4.00^{c}$ & $37.6 \pm 3.97 \mathrm{de}$ \\
\hline & $\mathrm{F}+\mathrm{A}$ & $1.753 \pm 0.006^{\mathrm{a}}$ & $1.374 \pm 0.007^{a}$ & $3.126 \pm 0.011^{a}$ & $0.605 \pm 0.006^{a}$ & $78.6 \pm 4.27^{a}$ & $63.4 \pm 3.84^{a}$ \\
\hline & $\mathrm{C}$ & $0.676 \pm 0.004^{l}$ & $0.356 \pm 0.005^{j}$ & $1.031 \pm 0.010^{\prime}$ & $0.179 \pm 0.002^{\prime}$ & $00.0 \pm 0.00^{h}$ & $00.0 \pm 0.00^{i}$ \\
\hline \multirow[t]{5}{*}{$12 \mathrm{dS} \mathrm{m}^{-1}$} & $\mathrm{~F}$ & $0.880 \pm 0.005^{h}$ & $0.785 \pm 0.011^{f}$ & $1.665 \pm 0.011 \mathrm{~g}$ & $0.224 \pm 0.003^{i}$ & $56.4 \pm 4.27^{d}$ & $24.4 \pm 3.20 \mathrm{~g}$ \\
\hline & A & $0.778 \pm 0.006^{j}$ & $0.376 \pm 0.011^{i}$ & $1.154 \pm 0.004^{j}$ & $0.286 \pm 0.002^{h}$ & $47.8 \pm 3.34^{\mathrm{e}}$ & $16.8 \pm 3.03^{h}$ \\
\hline & $\mathrm{F}+\mathrm{A}$ & $0.957 \pm 0.004^{f}$ & $0.868 \pm 0.012^{\mathrm{e}}$ & $1.826 \pm 0.015^{f}$ & $0.408 \pm 0.007 \mathrm{e}$ & $59.2 \pm 3.49^{d}$ & $40.2 \pm 4.32^{d}$ \\
\hline & L.S.D $(P \leq 0.05)$ & 0.007 & 0.0138 & 0.0181 & 0.003 & 4.8759 & 4.596 \\
\hline & ANOVA F $_{(11,24)}$ & 185.540 & 625.5300 & 135.3400 & 176.240 & 291.9640 & 192.735 \\
\hline \multirow[t]{3}{*}{ F values } & Salinity (S) & 36225.831 & 8310.8940 & 22637.2480 & 17434.234 & 128.7240 & 148.113 \\
\hline & Treatments ( $\mathrm{T}$ ) & 33582.465 & 15861.2330 & 30146.8350 & 48110.463 & 979.4900 & 583.236 \\
\hline & $\mathrm{S} \times \mathrm{T}$ & 5148.889 & 766.3310 & 2183.4160 & 2442.499 & 2.6230 & 12.358 \\
\hline
\end{tabular}

Legend: F+: Funneliformis mosseae, A: Acaulospora laevis, $\neq$ : each value is the mean of five replicates, \pm : standard deviation, AM: Arbuscular mycorrhizae, FW: fresh weight, values in columns followed by the same letter are not significantly different, $\mathrm{P} \leq 0.05$, least significant difference test. 
levels greater than $8 \mathrm{dS} \mathrm{m}^{-1}$ there was a marked increase in peroxidase activity associated with the stress induced damage. Single inoculation with A. laevis was less effective than a single inoculation with $F$. mosseae at all the salinity levels. Of the different treatments, the $\mathrm{F}+\mathrm{A}$ combination resulted in the highest peroxidase activity at low and medium salinity levels, but inoculation with F. mosseae alone resulted in the maximum activity being recorded at the highest salinity level used.

\section{Phosphatase Activity}

Both in mycorrhizal and non-mycorrhizal control plants the maximum values of acid and alkaline phosphatase activity was recorded at a salinity level of $8 \mathrm{dS} \mathrm{m}^{-1}$. At a salinity level of $12 \mathrm{dS} \mathrm{m}^{-1}$ the activity of both these enzymes decreased, however, the dual treatment $\mathrm{F}+\mathrm{A}$ resulted in a greater increase in enzyme activity than the single treatment with either of the mycorrhizal fungi at all salinity levels (Table 3 ).

\section{Electrolyte Leakage}

In this study, increase in salt concentration in the soil above a salinity level of $8 \mathrm{dS} \mathrm{m}^{-1}$ resulted in a decrease in membrane stability. The double inoculation treatment with $\mathrm{F}+\mathrm{A}$ at all the levels of salinity improved membrane stability, followed by a single treatment with $F$. mosseae. Less electrolyte leakage was recorded from mycorrhizal plants than non-mycorrhizal control plants at all the salinity levels used (Table 3).

\section{Nutrient uptake \\ Phosphorus, Potassium and Nitrogen}

In the present investigation, highest root and shoot phosphorus $(\mathrm{P})$ content was recorded at the medium salinity level i.e. $8 \mathrm{dS} \mathrm{m}^{-1}$ in the double inoculation treatment $\mathrm{F}+\mathrm{A}$ (Table 4). The combination of F. mosseae and A. laevis at all the salinity levels resulted in better root and shoot phosphorus contents than in the controls. Potassium $(\mathrm{K})$ and nitrogen $(\mathrm{N})$ uptake decreased with increase in salt concentration in the soil (Table 4). Mycorrhizal treatment increased potassium and nitrogen content in roots and shoots regardless of salt stress levels. Among the treated plants, treatment with $A$. laevis resulted in the least root and shoot potassium content at all salinity levels. Root potassium content was greater than that recorded in the shoots. Maximum shoot and root nitrogen uptake was recorded at $4 \mathrm{dS} \mathrm{m}^{-1}$ salinity level in treatment $\mathrm{F}+\mathrm{A}$. Shoots of $P$. mungo accumulated more nitrogen than the roots at all of the different levels of salinity used.

\section{Yield}

Since $P$. mungo is cultivated for its seeds, the effect of mycorrhizal inoculation on number and weight of pods under saline conditions is important. Mycorrhizal inoculation significantly increased yield of $P$. mungo compared to un-inoculated control plants at all the different levels of salinity used. At the $8 \mathrm{dS} \mathrm{m}^{-1}$ salinity level, maximum yield in terms of number and weight of pods per plant was recorded in the $\mathrm{F}+\mathrm{A}$ treatment, followed that re-

Table 3 Effect of AM fungi on some biochemical parameters of Phaseolus mungo grown under different levels of salinity stress.

\begin{tabular}{|c|c|c|c|c|c|}
\hline \multirow{2}{*}{$\begin{array}{l}\text { Salinity } \\
\text { level }\end{array}$} & \multirow{2}{*}{$\begin{array}{l}\text { Parameters } \rightarrow \\
\text { Treatments } \downarrow\end{array}$} & \multicolumn{2}{|c|}{ Phosphatase activity (IU/g FW) } & \multirow{2}{*}{$\begin{array}{l}\text { Peroxidase activity } \\
\text { (mg protein / } 10 \text { min) }\end{array}$} & \multirow{2}{*}{$\begin{array}{c}\text { Electrolyte } \\
\text { leakage (\%) }\end{array}$} \\
\hline & & Acidic & Alkaline & & \\
\hline & $\mathrm{C}$ & $0.030 \pm 0.006^{c}$ & $0.076 \pm 0.008^{h}$ & $0.242 \pm 0.011^{j}$ & $39.74 \pm 0.476^{b}$ \\
\hline \multirow[t]{4}{*}{$4 \mathrm{dS} \mathrm{m}^{-1}$} & $\mathrm{~F}$ & $0.138 \pm 0.010^{\mathrm{abc}}$ & $0.295 \pm 0.010^{c}$ & $0.599 \pm 0.004^{d}$ & $33.36 \pm 0.192 \mathrm{~g}$ \\
\hline & $A$ & $0.066 \pm 0.006^{b c}$ & $0.158 \pm 0.007^{e}$ & $0.486 \pm 0.013^{f}$ & $36.98 \pm 0.503^{d}$ \\
\hline & $F+A$ & $0.194 \pm 0.008^{a b}$ & $0.321 \pm 0.005^{b}$ & $0.812 \pm 0.002^{b}$ & $29.74 \pm 0.252^{h}$ \\
\hline & $C$ & $0.038 \pm 0.007^{c}$ & $0.082 \pm 0.006^{g h}$ & $0.161 \pm 0.020^{k}$ & $35.34 \pm 0.315^{\mathrm{e}}$ \\
\hline \multirow[t]{4}{*}{$8 \mathrm{dS} \mathrm{m^{-1 }}$} & $\mathrm{F}$ & $0.195 \pm 0.007^{a b}$ & $0.328 \pm 0.008^{b}$ & $0.315 \pm 0.009^{h}$ & $28.13 \pm 0.208^{i}$ \\
\hline & $A$ & $0.125 \pm 0.006^{a b c}$ & $0.258 \pm 0.007^{d}$ & $0.243 \pm 0.011^{j}$ & $29.85 \pm 0.194^{h}$ \\
\hline & $\mathrm{F}+\mathrm{A}$ & $0.240 \pm 0.008^{a}$ & $0.387 \pm 0.006^{a}$ & $0.405 \pm 0.006^{9}$ & $25.76 \pm 0.742^{j}$ \\
\hline & $\mathrm{C}$ & $0.024 \pm 0.005^{c}$ & $0.045 \pm 0.006^{i}$ & $0.297 \pm 0.018^{i}$ & $42.82 \pm 1.550^{a}$ \\
\hline \multirow[t]{5}{*}{$12 \mathrm{dS} \mathrm{m}^{-1}$} & $\mathrm{~F}$ & $0.075 \pm 0.006^{b c}$ & $0.116 \pm 0.008^{f}$ & $0.856 \pm 0.001^{a}$ & $38.73 \pm 0.396^{c}$ \\
\hline & A & $0.043 \pm 0.008^{c}$ & $0.090 \pm 0.005^{9}$ & $0.520 \pm 0.008^{e}$ & $40.29 \pm 0.277^{b}$ \\
\hline & $F+A$ & $0.153 \pm 0.007^{a b c}$ & $0.288 \pm 0.006 c$ & $0.764 \pm 0.004^{c}$ & $34.62 \pm 0.251^{f}$ \\
\hline & L.S.D $(P \leq 0.05)$ & 0.1231 & 0.0101 & 0.015 & 0.733 \\
\hline & ANOVA F $_{(11,24)}$ & 3.7830 & 132.6300 & 233.530 & 499.604 \\
\hline \multirow[t]{3}{*}{ F values } & Salinity (S) & 1.4230 & 1530.1650 & 4828.379 & 1485.808 \\
\hline & Parameter $(\mathrm{T})$ & 11.7500 & 3459.0210 & 4474.442 & 806.357 \\
\hline & $\mathrm{S} \times \mathrm{T}$ & 0.5850 & 191.0380 & 433.999 & 17.493 \\
\hline
\end{tabular}

Legend: Ft: Funneliformis mosseae, A: Acaulospora laevis, $\neq$ : each value is the mean of five replicates, \pm : standard deviation, AM: Arbuscular mycorrhizae, FW: Fresh Weight, values in columns followed by the same letter are not significantly different, P $\leq 0.05$, least significant difference test. 
corded for plants inoculated with same combination at the $4 \mathrm{dS} \mathrm{m}^{-1}$ salinity level (Table 5). Single treatment with F. mosseae also resulted in an increase in yield at all the different salinity levels compared to A. laevis. Soil salinity levels of $12 \mathrm{dS} \mathrm{m}^{-1}$ had a significant adverse effect on yield as the number and weight of pods were lower.

\section{Discussion}

Our results indicate that plant height, root length and biomass increased with increase in soil salinity up to $8 \mathrm{dS} \mathrm{m}^{-1}$, but were all less at the $12 \mathrm{dS} \mathrm{m}^{-1}$ salinity level. In Vicia faba increase in plant height at medium and low sa-

Table 4 Effect of AM fungi on nutrient uptake of Phaseolus mungo grown under different levels of salinity stress.

\begin{tabular}{|c|c|c|c|c|c|c|c|}
\hline \multirow{2}{*}{$\begin{array}{l}\text { Salinity } \\
\text { level }\end{array}$} & \multirow{2}{*}{$\begin{array}{l}\text { Parameters } \rightarrow \\
\text { Treatments } \downarrow\end{array}$} & \multicolumn{2}{|c|}{ Phosphorus content (\%) } & \multicolumn{2}{|c|}{ Nitrogen content (\%) } & \multicolumn{2}{|c|}{ Potassium content (\%) } \\
\hline & & Root & Shoot & Root & Shoot & Root & Shoot \\
\hline & $\mathrm{C}$ & $0.676 \pm 0.011^{i}$ & $0.449 \pm 0.008^{j}$ & $0.301 \pm 0.0030^{\text {def }}$ & $0.444 \pm 0.0348^{h}$ & $0.974 \pm 0.038^{h}$ & $0.708 \pm 0.05879$ \\
\hline \multirow[t]{4}{*}{$4 \mathrm{dS} \mathrm{m}^{-1}$} & $\mathrm{~F}$ & $1.269 \pm 0.005^{\mathrm{de}}$ & $0.694 \pm 0.007^{f}$ & $1.212 \pm 0.4022^{b}$ & $1.678 \pm 0.018^{b}$ & $1.906 \pm 0.0288^{c}$ & $1.035 \pm 0.0587 c$ \\
\hline & $A$ & $1.133 \pm 0.008^{f g}$ & $0.643 \pm 0.0039$ & $0.616 \pm 0.0320^{c}$ & $1.300 \pm 0.0029^{c}$ & $1.660 \pm 0.0223^{e}$ & $0.972 \pm 0.0192^{d}$ \\
\hline & $\mathrm{F}+\mathrm{A}$ & $2.181 \pm 0.007^{b}$ & $1.257 \pm 0.005^{b}$ & $1.430 \pm 0.0246^{a}$ & $1.931 \pm 0.00273^{a}$ & $2.324 \pm 0.0207^{a}$ & $1.232 \pm 0.1041^{a}$ \\
\hline & $\mathrm{C}$ & $0.806 \pm 0.007^{h}$ & $0.507 \pm 0.007^{i}$ & $0.206 \pm 0.0288^{f g}$ & $0.298 \pm 0.0225^{i}$ & $0.828 \pm 0.0238^{i}$ & $0.576 \pm 0.0240^{h}$ \\
\hline \multirow[t]{4}{*}{$8 \mathrm{dS} \mathrm{m}^{-1}$} & $\mathrm{~F}$ & $1.337 \pm 0.008^{d}$ & $0.846 \pm 0.006^{d}$ & $0.720 \pm 0.0254^{c}$ & $0.820 \pm 0.0269 \mathrm{e}$ & $1.748 \pm 0.0414^{d}$ & $0.920 \pm 0.0316^{\mathrm{de}}$ \\
\hline & $A$ & $1.295 \pm 0.006^{\mathrm{de}}$ & $0.713 \pm 0.006^{e}$ & $0.448 \pm 0.0319^{d}$ & $0.670 \pm 0.0247^{f}$ & $1.538 \pm 0.0319^{f}$ & $0.840 \pm 0.0314^{f}$ \\
\hline & $\mathrm{F}+\mathrm{A}$ & $2.431 \pm 0.286^{a}$ & $1.400 \pm 0.002^{\mathrm{a}}$ & $0.744 \pm 0.0384^{c}$ & $1.017 \pm 0.0599 d$ & $2.026 \pm 0.1040^{b}$ & $1.124 \pm 0.0288^{b}$ \\
\hline & C & $0.623 \pm 0.008^{i}$ & $0.395 \pm 0.005^{k}$ & $0.124 \pm 0.0230 \mathrm{~g}$ & $0.148 \pm 0.0258^{j}$ & $0.644 \pm 0.6270^{j}$ & $0.432 \pm 0.0286^{i}$ \\
\hline \multirow[t]{5}{*}{$12 \mathrm{dS} \mathrm{m}^{-1}$} & $\mathrm{~F}$ & $1.187 \pm 0.008^{e f}$ & $0.630 \pm 0.011^{h}$ & $0.389 \pm 0.0320^{\text {de }}$ & $0.524 \pm 0.03039$ & $1.636 \pm 0.0270^{e}$ & $0.898 \pm 0.0238^{e}$ \\
\hline & $A$ & $1.063 \pm 0.0079$ & $0.513 \pm 0.006^{i}$ & $0.228 \pm 0.0356^{\mathrm{efg}}$ & $0.4722 \pm 0.0030^{h}$ & $1.220 \pm 0.62549$ & $0.724 \pm 0.03049$ \\
\hline & $\mathrm{F}+\mathrm{A}$ & $1.858 \pm 0.017^{c}$ & $0.975 \pm 0.006^{c}$ & $0.684 \pm 0.0336^{c}$ & $0.791 \pm 0.0028^{e}$ & $1.946 \pm 0.0201^{c}$ & $1.044 \pm 0.0384^{c}$ \\
\hline & L.S.D $(P \leq 0.05)$ & 0.113 & 0.009 & 0.152 & 0.224 & 0.055 & 0.052 \\
\hline & ANOVA F $_{(11,24)}$ & 233.006 & 103.540 & 56.818 & 2112.724 & 795.512 & 133.440 \\
\hline \multirow[t]{3}{*}{ F values } & Salinity (S) & 58.545 & 5894.968 & 109.260 & 5500.719 & 372.964 & 105.774 \\
\hline & Treatments $(T)$ & 800.891 & 32949.820 & 116.998 & 3412.981 & 2645.806 & 410.992 \\
\hline & $\mathrm{S} \times \mathrm{T}$ & 7.218 & 532.687 & 10.913 & 333.264 & 11.217 & 3.894 \\
\hline
\end{tabular}

Legend: F†: Funneliformis mosseae, A: Acaulospora laevis, $\neq$ : each value is the mean of five replicates, \pm : standard deviation AM: Arbuscular mycorrhizae, values in columns followed by the same letter are not significantly different, $\mathrm{P} \leq 0.05$, least significant difference test.

Table 5 Effect of AM fungi on leaf area, nodules and yield of Phaseolus mungo grown under different levels of salinity stress.

\begin{tabular}{|c|c|c|c|c|c|}
\hline \multirow{2}{*}{$\begin{array}{l}\text { Salinity } \\
\text { level }\end{array}$} & \multirow{2}{*}{$\begin{array}{l}\text { Parameters } \rightarrow \\
\text { Treatments } \downarrow\end{array}$} & \multirow[t]{2}{*}{ Leaf Area } & \multirow{2}{*}{$\begin{array}{l}\text { No of nodules } \\
\text { (per pot) }\end{array}$} & \multicolumn{2}{|c|}{ Yield (per plant) } \\
\hline & & & & No. of pods & Weight of pods (g) \\
\hline & C & $08.22 \pm 1.522^{\mathrm{fg}}$ & $07.8 \pm 2.387 e$ & $03.0 \pm 1.581^{d}$ & $1.294 \pm 0.343^{\mathrm{fg}}$ \\
\hline \multirow[t]{4}{*}{$4 \mathrm{dS} \mathrm{m} \mathrm{m}^{-1}$} & $\mathrm{~F}$ & $18.31 \pm 1.598^{c}$ & $12.8 \pm 2.432^{\mathrm{cd}}$ & $05.6 \pm 2.302^{\mathrm{abcd}}$ & $1.916 \pm 0.379 \mathrm{de}$ \\
\hline & $A$ & $13.76 \pm 1.842^{d}$ & $10.2 \pm 1.923^{\mathrm{de}}$ & $03.6 \pm 2.073^{c d}$ & $1.556 \pm 0.438^{\mathrm{ef}}$ \\
\hline & $F+A$ & $25.50 \pm 2.214^{b}$ & $17.0 \pm 2.915^{b}$ & $07.8 \pm 1.923^{a b}$ & $3.040 \pm 0.436^{b}$ \\
\hline & C & $10.34 \pm 2.226^{f}$ & $03.8 \pm 2.387^{f g}$ & $04.0 \pm 2.549 \mathrm{~cd}$ & $1.510 \pm 0.395^{\mathrm{ef}}$ \\
\hline \multirow[t]{4}{*}{$8 \mathrm{dS} \mathrm{m} \mathrm{m}^{-1}$} & $\mathrm{~F}$ & $20.78 \pm 2.554 c$ & $15.6 \pm 3.209 \mathrm{bc}$ & $06.6 \pm 2.408^{\mathrm{abc}}$ & $2.390 \pm 0.382^{\mathrm{cd}}$ \\
\hline & $A$ & $15.45 \pm 2.019^{d}$ & $13.6 \pm 3.209 \mathrm{bcd}$ & $04.6 \pm 2.701 \mathrm{bcd}$ & $1.868 \pm 0.366 \mathrm{e}$ \\
\hline & $\mathrm{F}+\mathrm{A}$ & $23.47 \pm 1.917^{b}$ & $21.0 \pm 2.738^{a}$ & $09.0 \pm 3.162^{\mathrm{a}}$ & $3.772 \pm 0.346^{a}$ \\
\hline & C & $06.76 \pm 2.2149$ & $02.2 \pm 1.788^{g}$ & $02.6 \pm 2.408^{d}$ & $0.858 \pm 0.2779$ \\
\hline \multirow[t]{5}{*}{$12 \mathrm{dS} \mathrm{m}^{-1}$} & $\mathrm{~F}$ & $13.09 \pm 1.770$ de & $09.0 \pm 3.535^{e}$ & $05.0 \pm 3.162^{b c d}$ & $1.228 \pm 0.445^{\mathrm{fg}}$ \\
\hline & $A$ & $10.86 \pm 2.245^{\mathrm{ef}}$ & $06.8 \pm 2.387^{e f}$ & $02.8 \pm 1.303^{d}$ & $1.034 \pm 0.201^{\mathrm{fg}}$ \\
\hline & $F+A$ & $29.26 \pm 2.414^{a}$ & $14.2 \pm 2.364^{b c}$ & $05.2 \pm 3.492^{\mathrm{bcd}}$ & $2.600 \pm 0.351 b c$ \\
\hline & L.S.D $(P \leq 0.05)$ & 2.7441 & 3.5661 & 3.3833 & 0.503 \\
\hline & ANOVA $_{(11,24)}$ & 63.6630 & 21.8740 & 3.2330 & 28.063 \\
\hline \multirow[t]{3}{*}{ F values } & Salinity (S) & 7.8950 & 22.3980 & 3.6940 & 33.374 \\
\hline & Treatments(T) & 206.5570 & 60.0710 & 8.7870 & 79.060 \\
\hline & $\mathrm{S} \times \mathrm{T}$ & 10.8060 & 2.6010 & 0.3030 & 0.793 \\
\hline
\end{tabular}

Legend: G†: Funneliformis mosseae, A: Acaulospora laevis $¥$ : each value is the mean of five replicates, \pm : standard deviation, AM: Arbuscular mycorrhizae values in columns followed by the same letter are not significantly different, $\mathrm{P} \leq 0.05$, least significant difference test. 
linity level is recorded by Amira and Qados (2010) while in ornamental Purslane, Alam et al. (2015) records an increase in fresh and dry shoot weight at a salinity level of 8 $\mathrm{dS} \mathrm{m}^{-1}$. Our results confirm the findings of Pessarakli et al. (2015) who note an increase in root biomass of the Distichlis spicata at medium salinity levels compared to that recorded in high and low salinity level treatments. Under salinity stress, plant growth and biomass is limited by a lower availability of nutrients and the energy expenditure necessary to nullify the toxic effects of $\mathrm{NaCl}$ and other salts. Mycorrhization increases growth and biomass of the host plant due to AM mediated enhanced nutrient acquisition, especially a better P nutrition (Sharifi et al. 2007; Colla et al. 2008). Salinity stress lowered the concentration of photosynthetic pigments due to the toxic effects of salt on nitrogen and magnesium absorption, which are vital constituents of chlorophyll (Kaya et al. 2009). Another reason could be the increased activity of chlorophyllase due to salinity stress, which resulted in the destruction of photosynthetic pigments. The greater chlorophyll content of plants inoculated with mycorrhizal fungi could be due to the increased uptake of magnesium and nitrogen by AM hyphae (Abdel Latef and Chaoxing 2011) or an increase in the activity of enzymes required for the synthesis of chlorophyll (Murkute et al. 2006). Due to the higher concentration of photosynthetic pigments, photosynthesis in mycorrhizal plants subjected to salinity stress is higher than in un-inoculated stressed plants (Abdel Latef and Chaoxing 2011), which resulted in increased growth.

Salinity stress up to salinity level $8 \mathrm{dS} \mathrm{m}^{-1}$ resulted in an increase in leaf protein content. The reason may be due to an accumulation of salt stress proteins, which help in establishing a proper cellular ion and osmotic homeostasis (Amini et al. 2007; Garcia et al. 2008). These proteins act as nitrogen reserves for plants, which can be utilized later. Further, the decrease in leaf protein content with increase in salinity up to $12 \mathrm{dS} \mathrm{m}^{-1}$ is due to a decrease in uptake and utilization of nitrogen, which is an essential element for protein synthesis (Kusano et al. 2011). Mycorrhizal inoculation of plants improved leaf protein content regardless of the salinity. Our findings are in agreement with those of Datta and Kulkarni (2014) who also report an increase in protein content in mycorrhizal plants subjected to salinity stress.

A high soil salinity may not reduce mycorrhization, as increased mycorrhization under high saline conditions is reported by Aliasgharzadeh et al. (2001) and Yamato et al. (2008). The upper limit of the salinity tolerance of the AMF used in the experiment was $12 \mathrm{dS} \mathrm{m}^{-1}$, the level at which spore number and mycorrhization were drastically reduced. Decreased mycorrhization in P. mungo plants at salinities above $8 \mathrm{dS} \mathrm{m}^{-1}$ could be due to the high $\mathrm{pH}$ associated with high salt concentrations inhibiting the germination of fungal spores. Even though high salinity caused a decrease in mycorrhization subsequent mycorrhizal dependency increased, which indicates that the symbiosis between roots and AM fungi strengthens once the association is established, which indicates the importance of this symbiosis for plant production under saline conditions (Rabie and Almadini 2005). There was a direct correlation between mycorrhization and nodulation in the present experiment indicating the stimulatory role of mycorrhizae on nodulation. In this experiment, mycorrhizal plants growing at all of the salinity levels used were less affected in terms of nodulation parameters than the control plants because the root exudation pattern was modified both quantitatively and qualitatively by AMF, which results in an increase in nodulation (Garg and Manchanda 2009).

Salinity stress in plants results in an increase in the production of ROS (Reactive Oxygen Species) and hence, oxidative stress, which has toxic effects on different biomolecules. As different antioxidant enzymes nullify the effect of damage induced by ROS, it is possible that this accounts for the high activity of peroxidase recorded at the highest salinity level i.e. $12 \mathrm{dS} \mathrm{m}^{-1}$. Increase in antioxidant enzyme activity with increase in salinity is confirmed by Hashem et al. (2015). At all the salinity levels used, there was a higher peroxidase activity in the treatment inoculated with mycorrhizal fungi, which support the findings of Alqarawi et al. (2014) and Abd Allah et al. (2015). Estimates of phosphatase activity in plants help to assess phosphorus metabolism in mycorrhizal plants as this enzyme is present in the vacuoles of AM hyphae (Tisserent et al. 1993). Mycorrhizal inoculation positively affected phosphatase activity. Our results confirm the findings of Peng et al. (2011) who report an increase in alkaline phosphatase activity in mycorrhizal Astragallus sinicus under saline conditions. The major organelle in plants adversely affected by soil salinity stress is the cell membrane, as peroxidation of lipids causes the solutes to leak through the membrane decreasing its stability (Kaya et al. 2009). Mycorrhizal inoculation of plants improved membrane stability due to higher antioxidant activity and phosphorus uptake. The decrease in electrolyte leakage in mycorrhizal plants recorded in this experiment confirms the findings of Abd Allah et al. (2015).

Phosphorus uptake was negatively affected at a soil salinity level of $12 \mathrm{dS} \mathrm{m}^{-1}$ because of the precipitation of phosphate $\left(\mathrm{H}_{2} \mathrm{PO}_{4}\right)$ ions by calcium, magnesium and zinc ions, which adversely affects the uptake of this element (Marshner 1994). Mycorrhizal fungi are able to solubilize the precipitated phosphorus, thus increasing the availability of this immobile element under saline conditions (Srividya et al. 2010). Another reason for the improved P uptake by mycorrhizal plants is the greater soil volume penetrated by their extra radical mycelium, which extends beyond nutrient depleted zones in the soil. In the present experiment, mycorrhizal inoculation of plants also improved potassium uptake under different salinity levels. Our results confirm the findings of Patel et al. (2010) and Abd Allah et al. (2015). The decrease in the uptake of potassium, with increase in salinity recorded in this experiment is due to a high concentration of so- 
dium within the root zone, which has an antagonistic effect. The elevated concentration of sodium and chloride ions interfere with potassium ion channels in the plasma membrane of root cells causing a decrease in the uptake of this nutrient. A possible reason for the increased $\mathrm{K}$ uptake by mycorrhizal plants is their ability to store sodium in vacuoles of root cells as well as intra-radical hyphae (Cantrell and Linderman 2001). Increase in the tolerance of mycorrhizal plants to saline conditions may be attributed to their increased biomass due to enhanced nutrient uptake, which results in the dilution of the toxic effects of ions (Campanelli et al. 2012). Like potassium, nitrogen content in the plants also decreased with increase in soil salinity. Increased nitrogen uptake by mycorrhizal plants could be attributed to the ability of the extra-radical mycelium of mycorrhizal fungi to absorb nitrate and ammonium and translocate nitrogen in the form of arginine (Guether et al. 2009). Another reason could be the AM mediated increase in activity of urease in the soil, which may help in breaking down urea and in the liberation of $\mathrm{NH}_{3}^{+}$or $\mathrm{NH}_{4}^{+}$ions (Zhao et al. 2010). Higher nitrogen uptake by the mycorrhizal plants helps them to maintain a greater concentration of photosynthetic pigments, proteins and other non-protein amino acids like proline, which are important in osmotic adjustment as osmoprotectants (Evelin et al. 2009).

Maximum yield at the medium salinity level was recorded in this experiment. Highest mycorrhization at the $8 \mathrm{dS} \mathrm{m}^{-1}$ salinity level helped the plants to cope up with the deleterious effects of the salinity, as it resulted in an increase in growth, $\mathrm{P}$ uptake, phosphatase activity, chlorophyll and protein content and decrease in electrolyte leakage. A $12 \mathrm{dS} \mathrm{m}^{-1}$ soil salinity level had an adverse effect on yield, as the number and weight of pods produced was significantly lower. The positive effect of mycorrhizal inoculations on yield under saline conditions is confirmed by the results of Hajiboland et al. (2010).

\section{Conclusion}

With increase in soil salinity levels up to $12 \mathrm{dS} \mathrm{m}^{-1}$ electrolyte leakage and peroxidase activity increased, whereas, photosynthetic pigments, nutrient uptake, leaf protein content, phosphatase activity, mycorrhization, nodulation and all the morphological parameters measured decreased. Although, mycorrhization decreased at high salinity levels, the AM treatment positively affected photosynthetic pigments, nutrient uptake, leaf protein content, phosphatase activity, mycorrhization, nodulation, peroxidase activity and growth and decreased membrane damage. The results of the present experiment indicate that the growing of $P$. mungo at a $8 \mathrm{dS} \mathrm{m}^{-1}$ salinity level after inoculation with a combination of $\mathrm{F}+\mathrm{A}$ should be recommended. The cultivation of this pulse legume, however, should be discouraged if the salinity level of the soil is nearly $12 \mathrm{dS} \mathrm{m}^{-1}$ or above.

\section{Acknowledgement}

Authors are thank the Chairman, Department of Botany, Kurukshetra University Kurukshetra for providing the infrastructure and laboratory facilities for carrying out this research.

\section{REFERENCES}

Abd Allah EF, Hashem AA, Alqarawi A, Alwathnani, HA (2015) Alleviation of adverse impact of cadmium stress in sunflower (Helianthus annuus L.) by arbuscular mycorrhizal fungi. Pak J Bot 47: 785-795.

Abdel Latef AA, Chaoxing H (2011) Effect of arbuscular mycorrhizal fungi on growth, mineral nutrition, antioxidant enzymes activity and fruit yield of tomato grown under salinity stress. Sci Hortic 127: 228-233.

Adholeya A, Gaur A (1994) Estimation of VAM fungal spores in soil. Mycorrhiza News 6: 10-11.

Ahanger MA, Abeer Hashem EF, Abd Allah Ahmad P (2014) Arbuscular Mycorrhiza in Crop Improvement under Environmental Stress. In: Ahmad P (ed) Emerging Technologies and Management of Crop Stress Tolerance, doi:10.1016/B978-0-12 -800875-1.00003-X.

Aiasgharzadeh N, Saleh Rastin N, Towfighi H, Alizadeh A (2001) Occurrence of arbuscular mycorrhizal fungi in saline soils of the Tabriz Plain of Iran in relation to some physical and chemical properties of soil. Mycorrhiza 11: 119-122.

Alam A, Juraimi AS, Rafii MY, Hamid AA (2015) Effect of Salinity on Biomass Yield and Physiological and Stem-Root Anatomical Characteristics of Purslane (Portulaca oleracea L.) Accessions. BioMed Research International doi:10.1155/2015/105695.

Alqarawi AA, Abd Allah EF, Hashem A (2014) Alleviation of salt-induced adverse impact via mycorrhizal fungi in Ephedra aphylla Forssk. J Plant Interact 9: 802-810.

Amini F, Ehsanpour AA, Hoang OT, Shin J S (2007) Protein pattern changes in tomato under in vitro salt stress. Russ J Plant Physiol 54: 464-471.

Amira MS, Qados A (2010) Mechanism of Nanosilicon-Mediated Alleviation of Salinity Stress in Faba Bean (Vicia faba L.) Plants. Am J Exp Agric 7: 0606.

Arnon DI (1949) Copper enzymes in isolated chloroplasts, polyphenoxidase in Beta vulgaris. Plant Physiol 24: 1-15.

Bell RW, Dell B (2008) Micronutrients for Sustainable Food, Feed, Fibre and Bioenergy Production. International Fertilizer Industry Association (IFA) Paris, France.

Beltrano J, Ruscitti M, Arango MC, Ronco M (2013) Effects of arbuscular mycorrhiza inoculation on plant growth, biological and physiological parameters and mineral nutrition in pepper grown under different salinity and P levels. J Soil Sci Plant Nutr 13: 123-141.

Bradford MM (1976) A rapid and sensitive method for the quantitation of microgram quantities of protein utilizing the principle of protein-dye binding. Anal Biochem 72: 248-254.

Campanelli A, Ruta C, DeMastro G, Morone-Fortunato I (2013) The role of arbuscular mycorrhizal fungi in alleviating salt stress in Medicago sativa L. car. Icon. Symbiosis 59: 65-76.

Cantrell IC, Linderman RG (2001) Preinoculation of lettuce and onion with VA mycorrhizal fungi reduces deleterious effects of soil salinity. Plant Soil 233: 269-281.

Colla G, Rouphael Y, Cardarelli M, Tullio M, Rivera CM, Rea E (2008) Alleviation of salt stress by arbuscular mycorrhizal in 
zucchini plants grown at low and high phosphorus concentration. Biol Fert Soils 44: 501-509.

Cucci G, Lacolla G, Pagliai M, Vignozzi N (2015) Effect of reclamation on the structure of silty-clay soils irrigated with saline-sodic waters. Int Agrophys 29: 23-30.

Datta P, Kulkarni M (2013) Growth response and dependency of Arachis hypogaea L. on two AM fungi under salinity stress. Indian J Agric Biochem 26: 18-24.

Dionisio-Sese ML, Tobita S (1998) Antioxidant responses of rice seedlings to salinity stress. Plant Sci 135: 1-9.

Evelin H, Kapoor R, Giri B (2009) Arbuscular mycorrhizal fungi in alleviation of salt stress: a review. Ann Bot 104: 1263-280.

Flowers TJ, Flowers SA (2005) Why does salinity pose such a difficult problem for plant breeders. Agric Water Management 78: $15-24$.

Garcia JL, Troncoso J, Cantos M, Troncoso A (2008) Differential protein expression in olive tissues due to salt treatment. Acta Hortic 791: 117-120.

Giovannetti M, Mosse B (1980) An evaluation of techniques for measuring vesicular-arbuscular mycorrhizal infection in roots. New Phytol 84: 489-500.

Guether M, Neuhäuser B, Balestrini R, Dynowski M, Ludewig U, Bonfante P (2009) A Mycorrhizal-Specific Ammonium Transporter from Lotus japonicus Acquires Nitrogen Released by Arbuscular Mycorrhizal Fungi. Plant Physiol 150: 73-83.

Hajiboland R, Aliasgharzadeh N, Laiegh SF, Poschenrieder C (2010) Colonization with arbuscular mycorrhizal fungi improves salinity tolerance of tomato (Solanum lycopersicum L.) plants. Plant Soil 331: 313-327.

Hashem A, Abd-Allah EF, Alqarawi AA, El-Didamony G, Alwhibi Mona S, Egamberdieva D, Ahmad P (2014) Alleviation of adverse impact of salinity on faba bean (Vicia faba L.) by arbuscular mycorrhizal fungi. Pak J Bot 46: 2003-2013.

Jackson ML (1973) Soil Chemical Analysis. Prentice Hall, New Delhi.

Kaya C, Ashraf M, Sonmez O, Aydemi S, Tuna LA, Cullu AM (2009) The influence of arbuscular mycorrhizal colonization on key growth parameters and fruit yield of pepper plants grown at high salinity. Sci Hort 121: 1-6.

Kusano M, Fukushima A, Redestig H, Saito K (2011) Metabolomic approaches toward understanding nitrogen metabolism in plants. J Exp Bot 62: 1439-1453.

Kusano M, Tohge T, Fukushima A, Kobayashi M, Hayashi N, Otsuki $\mathrm{H}$, Kondou Y, Goto H, Kawashima M, Matsuda F, Niida R, Matsui M, Saito K, Fernie AR (2011) Metabolomics reveals comprehensive reprogramming involving two independent metabolic responses of Arabidopsis to UV-B light. Plant J 67: 354-369.

Marschner H (1995) Mineral nutrition of higher plants. 2nd edn. New York, NY: Academic Press, London.

Menge JA, Timmer LW (1982) Procedure for inoculation of plants with VAM in the laboratory, greenhouse and field. In: Schenck NC (ed) Methods and principles of mycorrhizal research. American Phytopathology Society, St Paul, pp 59-67.

Morton JB, Benny GL (1990) Revised classification of arbuscular mycorrhizal fungi (Zygomycetes): A new order, Glomales, two new suborders, Glomineae and Gigasporineae, with an remendation of Glomaceae. Mycotaxon 37: 471-491.

Mukerji KG (1996) Taxonomy of endomycorrhizal fungi. In: Mukerji KG, Mathur B, Chamola BP, Chitralekha P (eds) Advances in Botany. APH Pubishing Company, New Delhi, pp 211-221.

Mukhopadhyaya NB, Rahmbhat A, Patel GJ (1986) Trichoderma harzianum - a potential biocontrol agent for tobacco damping off. Nicotine Tob Res 12: 26-35.
Munns R (2005) Genes and salt tolerance: bringing them together. New Phytol 167: 645-663.

Murkute AA, Sharma S, Singh SK (2006) Studies on salt stress tolerance of citrus rootstock genotypes with arbuscular mycorrhizal fungi. Hort Sci 33: 70-76.

Parvaiz A, Satyawati S (2008) Salt stress and phyto-biochemical responses of plants - a review. Plant Soil Environ 54: 89-99.

Patel PR, Sushil SK, Vinay RP, Vimal JP, Khristi SM (2010) Impact of salt stress on nutrient uptake and growth of cowpea. Braz J Plant Physiol 22: 43-48.

Peng J, Li Y, Shi P, Chen X, Lin H, Bin Zhao (2011) The differential behavior of arbuscular mycorrhizal fungi in interaction with Astragalus sinicus L. under salt stress. Mycorrhiza 21: 27-33.

Pessarakli M, Marcum KB, Kopec DM (2001) Growth Responses of Desert Saltgrass under Salt Stress. A part of the University of Arizona College of Agriculture 2001, Turfgrass and Ornamental Research Report.

Phillips JM, Hayman DS (1970) Improved procedures for clearing roots and staining parasitic and VAM fungi for rapid assessment of infection. Trans Brit Mycol Soc 55: 158-161.

Rabie GH, Almadini AM (2005) Role of bioinoculants in development of salt-tolerance of Vicia faba plants under salinity stress. Afr J Biotechnol 4: 210-223.

Ruiz-Lozano JM, Azcón R, Goméz M (1996) Alleviation of salt stress by arbuscular mycorrhizal Glomus species in Lactuca sativa plants. Physiol Plant 98: 767-772.

Sarwar G, Sadiq MS, Saleem M, Abbas G (2004) Selection criteria in F3 and F4 population of mungbean (Vigna radiata (L.) Wilczek). Pak J Bot 36: 297-310.

Schenck NC, Perez Y (1990) Manual for the identification of VA mycorrhizal VAM fungi. University of Florida Press, Florida, USA.

Sharifi M, Ghorbanli M, Ebrahimzadeh H (2007) Improved growth of salinity-stressed soybean after inoculation with pre-treated mycorrhizal fungi. J Plant Physiol 164: 1144-1151.

Sheng M, Tang M, Zhang F, Huang Y (2011) Influence of arbuscular mycorrhiza on organic solutes in maize leaves under salt stress. Mycorrhiza 21: 423-430.

Srividya S, Soumya S, Pooja K (2010) Influence of environmental factors and salinity on phosphate solubilization by a newly isolated Aspergillus niger F7 from agricultural soil. Afr J Biotechnol 8: 1864-1870.

Tabatabai MA, Bremner JM (1969) Use of p-nitrophenyl phosphate for assay of soil phosphatase activity. Soil Biol Biochem 1: 301-307.

Tisserant B, Gianinazzi-Pearson V, Gianinazzi S, Gollotte A (1993) In planta histochemical staining of fungal alkaline phosphatase activity for analysis of efficient arbuscular mycorrhizal infections. Mycol Res 97: 245-250.

Turkmen O, Demir S, Sensoy S, Dursun A (2005) Effects of arbuscular mycorrhizal fungus and humic acid on the seedling development and nutrient content of pepper grown under saline soil conditions. J Biol Sci 5: 568-574.

Weaver RW, Fredrick LR (1982) Rhizobium. Methods of soil analysis Part 2. Chemical and microbiological properties. Agronomy monograph, No. 9, 2nd Edition. American society for agronomy, Madison, pp 1043-1070.

Yamato M, Ikeda S, Iwase K (2008) Community of arbuscular mycorrhizal fungi in coastal vegetation on Okinawa Island and effect of the isolated fungi on growth of sorghum under salt-treated conditions. Mycorrhiza 18: 241-249.

Zhao M, Li M, Liu RJ (2010) Effects of arbuscular mycorrhizae on microbial population and enzyme activity in replant soil used for watermelon production. Int J Eng Sci Tech 2: 17-22. 